\section{What a difference a virus makes!}

\author{
Philip Wiffen
}

A couple of months ago I wrote an editorial for the March issue of the European Journal of Hospital Pharmacy (EJHP) fully expecting it to be read by many Congress delegates. I suggested that either the virus would have gone away or be worse by Congress. Little did I think that Congress might be postponed. At that time it was confined largely to Asia. Now we are all in the midst of a global pandemic wondering what will happen next. Several months ago, any government that told its citizens that they must not go out, were closing all shops, pubs, theatres, restaurants and gyms apart from food and

Correspondence to Professor Philip Wiffen, Pain Research Unit, Churchill Hospital, Oxford OX3 7LE, UK; pwiffen@oxfordsrs.org.uk pharmacies, would have been met by public outcry, however that is now the new normal. This is apart from financial challenges, loss of income for many, a good deal of fear and an increasing number of deaths.

You will not be surprised that many of the EJHP editors are on the front line across Europe and working 12-hour days in some cases; in addition those we rely on to be peer referees are in similar positions. With that in mind we have decided to suspend the management of new submissions until the end of April in the first instance. What this means in practice is that papers that are considered unsuitable will be rejected as quickly as possible but others will be held until we are able to move papers on to review and decisions. That said, we are in a position to deliver EJHP on schedule for the next few issues and with a full range of papers.

Italy is one of those countries that has been hit hard by the virus with around $10 \%$ of the number infected dying. That figure is far higher than other countries at the time of writing. I am pleased that this short editorial is followed by one giving a view from that country.

\section{Competing interests None declared.}

Provenance and peer review Commissioned; internally peer reviewed.

(c) European Association of Hospital Pharmacists 2020. No commercial re-use. See rights and permissions. Published by BMJ.

\section{Check for updates}

To cite Wiffen P. Eur J Hosp Pharm 2020;27:129.

Eur J Hosp Pharm 2020;27:129.

doi:10.1136/ejhpharm-2020-002300

ORCID iD

Philip Wiffen http://orcid.org/0000-0001-6085-1307 